\author{
Mariama Marciana Ku u sa a na (Kwame Nkrumah University of Science \\ and Technology, Kumasi, Ghana) \\ ORCID: 0000-0002-6711-0867 \\ Samuel A d u-Gy a m fi (Kwame Nkrumah University of Science \\ and Technology, Kumasi, Ghana) \\ ORCID: 0000-0002-0193-867X \\ mcgyamfi@yahoo.com \\ Benjamin Dompreh Darkw a (University of Alberta, Canada) \\ ORCID: 0000-0003-1662-9789
}

\title{
COCOA PRODUCTION IN GHANA (1879-1976)
}

\begin{abstract}
Cocoa production has been a major source of income and revenue to many citizens and the governor of Ghana respectively through time. Historically, although attributed to Tetteh Quarshie, records have shown that prior to Tetteh Quarshie's achievement, the Dutch and Basel Missionaries had experimented with the crop in the Gold Coast. Since its introduction in the country, cocoa production has expanded and spread across all the regions in Ghana. The production of cocoa has affected every facet of development in the country since its inception and has once led Ghana to be world's major exporter of the beans. Cocoa production in Ghana has gone beyond its agricultural and economic significance with its impacts felt across socio-cultural, religious and political life of Ghanaians. That notwithstanding, scholars have made partial effort at addressing the impact of cocoa production among Ghanaians between 1879 and 1976. Using a qualitative approach rooted in both primary and secondary sources, the current study sought to address the gap aforementioned by tracing the relationship between cocoa production and economics, politics and social-religious practices among Ghanaian between 1879 and 1976. Findings from the discourse revealed that though an agricultural product, cocoa can no longer be said to belong to that sphere alone. The product and its associated gains have permeated the entire life of Ghanaians since its inception.
\end{abstract}

Keywords: Cocoa, Ghana, Impact, Production, Industry

doi: 10.2478/sho-2021-0003 


\section{INTRODUCTION}

Although commercial cultivation of cocoa in Ghana is attributed to Tetteh Quarshie, he was not the first person to have introduced the crop to Ghana. Historically, the Dutch are reported to have cultivated the crop as far back as 1815 along the coastal areas of the then Gold Coast [Oppong-Boateng J. 2014; Tetteh S. 2019]. In 1858, the Basel Missionaries also introduced cocoa together with coffee from Surinam [Oppong-Boateng J. 2014]. Both crops were planted at Akropong, with coffee surviving while cocoa died out with time. Another individual associated with the introduction of cocoa to Ghana is Sir William Bradford Griffith, a former Governor of the Gold Coast, who is said to have experimented with the crop which he brought from Sao Tome in 1886 [Akuamoa G.K. 2011]. He raised the seedlings at the Aburi Botanical Gardens and distributed them to local farmers. However, like the Basel missionaries, nothing of his effort went beyond the experimental stage.

Having been trained as a blacksmith under the tutelage of the Basel missionaries, Tetteh Quarshie sojourned for a while at Fernando Po (now Bioko) in Equatorial Guinea where he obtained the seed of the golden pod [Oppong-Boateng J. 2014: 13]. Back in Ghana in 1879, Quarshie started cultivating the cocoa crop. Unlike the much earlier efforts, he became successful and since then cocoa became the major cash crop in Ghana. The venture into cocoa production in Ghana since the year 1879 by Tetteh Quarshie gradually expanded the cultivation of the crop and spread from Mampong-Akwapim (where he started his cocoa farm) to other areas in the country. From this period under consideration, Ghana rose to become the leading producer of cocoa in the world, eclipsing all other cash crops in the country (1911-1976) [Darkwah S.A., Verter N. 2014: 296]. As a major employer of labour and source of income to many Ghanaians, the production of cocoa in the country contributed about $30-40 \%$ of total output [Darkwah S.A., Verter N. 2014: 296]. Since its introduction, cocoa production in Ghana transformed its spheres and has since transcended its agricultural and economic significance.

The contribution of cocoa to the economy of Ghana and Africa in general has been well documented. Economically, the production of cocoa crops yields higher revenue to the governments of West Africa [Agbodeka F. 1992: 41-2]. Across developing countries and Africa in particular, scholars have reported that export crops like cocoa have been the tradi- 
tional sources of foreign exchange earnings and revenues for government [Wessel M., Quist-Wessel P.M.F. 2017: 3].

In Ghana, not only has the crop contributed to foreign exchange generation and growth of Gross Domestic Product (GDP). In fact, the country's case has witnessed the combination of both favorable external and internal reforms concerning cocoa production to contribute to economic growth and poverty reduction across the country Across developing countries and Africa in particular, scholars have reported that export crops like cocoa have been the traditional sources of foreign exchange earnings and revenues for government [Wessel M., Quist-Wessel P.M.F. 2017: 1-3].

It has been reported that the dawn of the $21^{\text {st }}$ century saw the increment in exportation of cocoa products from 2,000,000 tons to about 3,000,000 tons in 2010 [Wessel M., Quist-Wessel P.M.F. 2017: 1]. Statistics indicate that the Ghanaian economy saw a gross increase in cocoa production from 300,000 tons in 1995 to 900, 000 tons in 2014 [Wessel M., QuistWessel P.M.F. 2017: 3]. Among other factors, scholars have reported that the increase in farm gates prices, introduction of free pest and disease control projects, distribution of fertilizers and hybrid seeds among others can be used as a major exegesis for the steadily growth in cocoa production [Wessel M., Quist-Wessel P.M.F. 2017: 1-7].

Consequently, cocoa has affected every facet of development in the country since its inception. Essentially, cocoa production phenomenally affected the socio-cultural, religious and political life of Ghanaians. Concerning cocoa in Ghana, since the era of the Gold Coast, several scholars have attempted to present discourses on the subject. Notable among these include the works of Adomako-Sarfo [1974], Agbodeka [1992], Tashjian and Allman [2002], Akuamoa [2011], Oppong-Boateng [2014] and Tetteh [2019]. Among other things, the aforementioned studies have focused on the economic dimension and contribution of cocoa. Also, the work of Agbodeka [1992], for instance, has noted that Ghana has witnessed ups-and-downs in the cocoa industry, and has been devoid of its position as the world's leading producer of cocoa in contemporary times. That notwithstanding, existing sources attest to the fact that the country's production levels have still been high and significant through time.

While scholars have paid attention to the economic contribution of the crop to the development of the country, same cannot be said about cocoa and socio-political relations in the country through time. Essentially, the impact of cocoa on social relations and politics has received limited scholarly attention. Thus, scholars have made partial effort at addressing 
the impact of cocoa production among Ghanaians between 1879 and 1976. This calls for the need to make a historiographical sketch concerning how the crop has shaped the Ghanaian society, its politics and culture through time.

The time frame chosen for this discourse is the period from 1879 to 1976. This period is significant because it marks the introduction of a new species of cocoa into Ghana by an indigene - Quarshie. Between the period of 1911 and 1976, the country rose as a leading producer of cocoa bean in the world [Darkwah S.A., Verter N.: 296]. In this regard, we are interested in discussion the impact of cocoa on the lives of indigenous people and the country at large since Tetteh Quarshie's achievement till the country's position as a leading world producer started retrogressing.

It is in the light of this gap that this paper attempts to highlight the implications and to fully appreciate the impact of cocoa production in Ghana within the era under review. In reaching the objectives enlisted above, the study uses a purely qualitative approach. Data has been gathered and analysed from both primary and secondary sources.

Concerning the primary sources, the authors collected and compiled data from a host of government records, reports and newspapers reports on cocoa. Importantly, emphasis was placed on reports from cocoa marketing and distribution reports that are in existence. The various historical documents were obtained from the Public Records and Archive Administration Departments in both Accra and Kumase in Ghana. Concerning the selection of primary data, emphasis was placed on reports that pay significant attention to the colonial and post-colonial era.

On the part of secondary sources, the authors obtained information from books, journal articles and internet sources that have discussions on the issues under study. In the course of our selection, we paid relevant attention to materials that present unbiased discussions. The data gleaned from both sources have been analyzed thematically. Also, in piecing this manuscript, data form both sources have been used to corroborate one another.

We have structured the current discourse into three major sections with various subsections. The first section introduces the study and sets the tone for the rest of the discourse. In the second section, we present the findings and discussions of the study. They have been presented under the following themes: The Economy of Cocoa in Ghana, where relationship between cocoa production and the economy of Ghana within the period under review has been established; Cocoa and Politics, which discusses 
how politics and cocoa production shaped each other during the period under discussion and Socio-Cultural and Religious Impact of Cocoa which sought to discuss the social dimension of cocoa. The last section concludes the study.

\section{THE ECONOMY OF COCOA IN GHANA}

As the dominant cash crop in Ghana, cocoa has contributed significantly to the growth of the economy of Ghana. The first recorded export of cocoa from Ghana was in 1885, worth 121 1b. Six years later in 1891, another shipment was made, and twenty years following this in 1911, Ghana had become the world's leading producer of cocoa [Kimble D. 1963: 3-4]. For much part of the twentieth century, Ghana occupied this position. The position of the country on the world market generated much revenue for the government of Gold Coast and the colonial power, Britain, in particular. Evidence from documentary sources indicate that no government dared take the revenue from cocoa for granted as it became a critical factor in government's fiscal policy and the lives of a high percentage of the population were tied with the cocoa industry [PRAAD Accra (RG7/2/245)].

Among other things, the revenue generation in itself led to an increase in cocoa production in the country. Increase in Gold Coast trade (imports and exports) shortly after the Second World War was directly or indirectly as a result of increase in cocoa production. The steady increase in cocoa exports from 1905-1923 is given below (Table 1).

The impact of the overwhelming growth of the cocoa industry permeated almost every aspect of Ghanaian life. It contributed largely to the growth of the money economy at the turn of the nineteenth century [Kimble D. 1963: 37]. British silver coins came into wide circulation and brought into being the need for monetary and banking services. In answering to such needs, there were the establishments of a Commercial Bank of West Africa with headquarters in Sierra Leone in 1882, the enactment of a Savings Bank Ordinance in 1887 and the establishment of the British Bank of West Africa in 1994 [Kimble D. 1963: 38].

The expansion in cocoa production also resulted in commercialization and individualization of land. Cultivation of the crop rested more on permanent land usage as opposed to that of food crops for which land could easily be shifted annually or within short intervals [Adu-Gyamfi S. et al. 2020]. Concerning cocoa production, farmers who were seeking 
Table 1: Gold Coast Cocoa Exports from 1905-1923

\begin{tabular}{|c|c|c|}
\hline Year & $\begin{array}{r}\text { Cocoa Exports } \\
\text { (Tons) }\end{array}$ & $\begin{array}{c}\text { Amount } \\
(£)\end{array}$ \\
\hline 1905 & 7,000 & 187,000 \\
1906 & 8,000 & 336,000 \\
1907 & 10,000 & 515,000 \\
1908 & 13,000 & 541,000 \\
1909 & 21,000 & 755,000 \\
1910 & 22,000 & 866,000 \\
1911 & 41,000 & $1,613,000$ \\
1912 & 39,000 & $1,641,000$ \\
1913 & 52,000 & $2,489,000$ \\
1914 & 53,000 & $2,194,000$ \\
1915 & 78,000 & $3,651,000$ \\
1916 & 73,000 & $3,484,000$ \\
1917 & 92,000 & $3,147,000$ \\
1918 & 67,000 & $1,797,000$ \\
1919 & 176,000 & $8,278,000$ \\
1920 & 125,000 & $10,056,000$ \\
1921 & 133,000 & $4,764,000$ \\
1922 & 159,000 & $5,841,000$ \\
1923 & 197,000 & $6,567,000$ \\
\hline
\end{tabular}

Source: [Metcalfe G. 1964: 595].

to expand their production base resorted to the acquisition of individual lands for their activities. In Asante, it has been noted that some farmers were fond of acquiring lands both within and without their communities to indulge in cocoa production [Adu-Gyamfi S. et al. 2020]. Similarly, in the Ivory Coast, it has been reported that cocoa farmers in the colonial era embarked on the search for new lands for cocoa production [Wessel M., Quist-Wessel P.M.F. 2017: 1].

In Ghana, it is believed that all lands that were suitable for cocoa cultivation in the Larteh area of Akwapim for example, were sold to cocoa farmers, many of whom were migrants [Kimble 1963: 35]. This rush for land did not however lead to plantation development in cocoa production, neither in the pioneering years nor presently. It has remained a small-scale farming venture. 
Yet, Polly Hill classifies it among what he calls rural capitalism [Hill P. 1970]. For the reasons underpinning this ambiguous classification of the cocoa migrant farmers as capitalists, Hill identifies the following factors: that they buy their land and regard cocoa growing as business; though generally not large-scale production, reasonably large tracts of land were involved in some cases; forming groups or companies as a commercial attitude to land purchase; maintaining ties with extended family and fulfilling obligations towards members; borrowing money or using own savings as capital; personal involvement in the work while coordinating and directing the activities of others; investing profits in other enterprises like wholesale trading or transport business; transformation of lives through cocoa business like building houses and educating children; and initiating developments like road construction and provision of other social amenities [Hill P. 1970: 22-9]. Hill believes that all these characteristics of capitalism were identifiable with the Ghanaian migrant farmer.

Importantly, the fluctuations in cocoa prices affected the economy of the cocoa industry and of land. On $25^{\text {th }}$ June, 1931, evidence from documentary sources have reported that the decrease in the prices of cocoa product led to the abandonment of cocoa farms and spurred the cultivation of food crops. Evidence of this was witnessed in Central and Western Provinces of Asante [PRAAD Accra (CSO 8/2/85)]. In contrast, a report from the office of the Director of Agriculture released on $20^{\text {th }}$ August of the same year indicated that:

No abandonment of farms is taking place. A single instance is only noted from Twifu in Central Province, where some farmers have decided to concentrate on corn growing from the Tarkwa, Takoradi and Sekondi Markets. There is also no evidence of abnormal neglect of farms... [PRAAD Accra (CSO 8/2/85)].

Regardless of the inconsistencies concerning whether cocoa farms were neglected or not, one thing is factual; it shaped the economy of land. From the data above, it can be suggested that the fluctuations in cocoa prices shifted the attention of some farmers towards cultivating food crops at the expense of the cocoa crop. Also, lands - that would have been used for cultivating cocoa- were used for planting for subsistence during the period under review.

From a different perspective, it can be argued that, economically, cocoa contributed to the development of rural communities within the period under review. The early railways to be constructed in Ghana passed through towns and cities linked to mining and cocoa growing areas like 
Sekondi-Takoradi, Tarkwa, and Kumase. Health facilities and other social amenities were also provided in cocoa growing communities for the benefit of the people. ${ }^{1}$

Across the country, the cocoa sector necessitated the establishment of sheds. In major farming and industrial towns these sheds were used as both storage and purchasing facilities. Initially, sheds were owned and controlled by European firms who acquired licenses for lands from government to operate. From 1936, the capitals that were accrued from the cocoa industry served as a strength for private individuals as they could establish and control their own sheds. Most of these private cocoa sheds were located in the Tarkwa, Asante, and Sekondi among others towns [PRAAD Accra (CSO/8/2/40)].

The demand and supply of labour became attached to cocoa production and related industries. Labour as an important factor of production emerged on an increasing scale and came along with it new labour relations. Concerning labour, cocoa provided a major source of income for sizeable proportion of the farming population [PRAAD Accra (RG7/2/245)]. The $a b u s a^{2}$ system was adopted to pay labourers on the cocoa farm a onethird share upon harvesting of the crop. Through time, the nkotokuano system also developed when marketing arrangements became more standardised. By this system, the labourer was given a fixed sum per load by his employer for all the cocoa he (the labourer) harvested [Kimble D. 1963: 40].

The economic boom in the cocoa industry brought new discussions in tune. Among the most important ones was the proposal for the establishment of a cocoa processing industry in the colony. While the movement towards this started earlier, it reached its peak in the first half of the 1960s. At the dawn of the 1960s, stakeholders anticipated for the establishment of a processing factory that would enhance the locally manufactured cocoa products. In line with this, the government sought to import experts from overseas to facilitate the process [PRAAD Accra (RG7/1/196)].

1 Why Ghana is Cocoa and Cocoa is Ghana, https://www.modernghana.com/ news/398737/why-ghana-is-cocoa-and... Retrieved on $4^{\text {th }}$ February, 2017.

2 Abusa is an Akan word used to in relation to a means of paying labourers. This had usually been common among Gold Coast farmers prior to the money economy. In this system, an agreement which espouses that upon harvesting, labourers will be paid one-third of the shares of the crop in question. 
Among other experts, Heinz G. Landeck from Israel who proposed to take the position stated in his letter to the Ministry of Industry on July 2, 1961 that:

I am a man with 25years experience and have worked in Germany, where I studied my profession, later worked in China and am employed here in Israel for the last 12years in one of the biggest sweets factories as a managing expert for the production of goods [PRAAD Accra (RG 7/1/196)].

The proposed company was to be set up as a 100,000 ton chocolate factory as a cooperative venture with the German Democratic Republic [PRAAD Accra (RG 7/1/196)]. These actions notwithstanding, the requests did not meet the political will of the day and was subsequently neglected as a future discourse. Importantly, inferences drawn from a letter written by the General Manager for the Industrial Co-Operative Society reported that the Ministry had ignored their actions towards the establishment of the processing company [PRAAD Accra (RG 7/1/196)].

Cocoa production in Ghana therefore contributed in no small measure to increased demand for the three factors of production namely; land, labour and capital, and resulted in redefinition of land tenure as well as labour relations.

\section{COCOA AND POLITICS IN GHANA}

As the major cash crop in Ghana, cocoa played various roles in national politics since colonial times. One of the features of the colonial economy in Africa was the role of the colony as a source of raw materials for the colonisers. Minerals like gold and diamonds and agricultural products like cocoa, coffee and vegetables oils were some of the most common raw materials which were locally produced and shipped out of the continent to Europe. Even till date, throughout Africa, almost every country is identifiable with at least a particular dominant cash crop, which is largely a remnant of the colonial state.

In Ghana, cultivation of cocoa from the very beginning has remained a private activity. Individuals procure both land and labour on their own. Government's involvement included purchasing and policy initiation to control cocoa diseases and regulation of the industry [Kay G. 1972: 238]. The political impact of cocoa can be traced to the colonial period. Nationalist activities and reaction to the unjust colonial economic system relat- 
ed to cocoa often came in the form of boycotts and hold-ups. Between 1920 and 1940, a number of such boycotts and hold-ups were staged against the colonial government. At the head of these activities were two firebrands, John Kwame Ayew of Akwapim and Winifried Tetteh Ansah (also called Musah) of Manya Krobo [Boahen A.A. 1975: 146-8].

Shortly after the First World War, Kwame Ayew formed the Gold Coast Cocoa Farmers' Association and spearheaded cocoa hold-ups in 1920-1 and 1930-31 which occurred mainly in the areas of Larteh, Dodowa, Akuapem and Akyem Abuakwa. In 1937, another hold-up was staged in Suhum and spread to surrounding places. The major issue at the centre of these cocoa-related agitations was the domination of the marketing of cocoa by the grand comptoirs, such as the UAC and the SCOA. Both Kwame Ayew and Tetteh Ansah were into cocoa marketing and the latter in particular, had established companies for the purpose. With a strong educational background in commerce and banking which he studied in America and Europe between 1919 and 1928, he returned to Ghana to start business in the cocoa industry [Boahen A.A. 1975: 146-8]. Between 1924 and 1933, Tetteh Ansah established the following five companies, but all went bankrupt within the period:

Table 2: Companies Established by Tetteh Ansah (1924-1933)

\begin{tabular}{|l|c|c|}
\hline \multicolumn{1}{|c|}{ Name of Company } & Year & Capital $(£)$ \\
\hline West African Cooperative Producers Limited & 1925 & 250000 \\
Industrial and Commercial Bank Limited & - & 100000 \\
West African American Corporation Incorporated & 1930 & 1000000 \\
Nigeria Mercantile Bank Limited & 1931 & - \\
African Producers' Cooperative Limited & 1932 & - \\
\hline
\end{tabular}

Source: [Boahen A.A. 1975: 147].

After this initial setback, he went ahead with John Ameyaw to form the Gold Coast and Asante National Product Institute (for organisng and coordinating farmers' cooperatives) and the National Cocoa Control Board (for marketing cocoa) in 1934. These two ventures ceased to exist in a year's time. Disappointed, Tetteh Ansah relocated to Europe and while sojourning in Canada, passed away under very obscure circumstances in 1941.

Comparatively, the hold-ups seemed effective as the colonial government was compelled by the volatile situation and the stagnation of 
economic life to set up a commission for investigation. It was realized that the 1937 hold-up was caused by an attempt made by the expatriate firms under the leadership of UAC to fix the price of cocoa without any form of consultation with the farmers. Indeed, the price of cocoa had been reduced by the cocoa pool [Agbodeka F. 1992: 42]. The cocoa pool was reprimanded by the commission and advised to withdraw its action. It also recommended to the government to allow farmers' cooperatives to be directly involved in the sale of cocoa to prevent unscrupulous middlemen from taking advantage of the farmers [Boahen A.A. 1975: 148].

Another political upheaval in the political period fueled partly by developments in the sector was the 1948 disturbances in the Gold Cost. Though a wide range of issues culminated in the riots, the outbreak of the swollen shoot disease of cocoa and the government's handling of the matter ignited resentment from the cocoa farmers, to add more vim to bring about the disturbances. The outbreak of the swollen shoot disease which was noticed in the 1930s had aggravated by the 1940s, affecting about 50 million of an estimated 400 million cocoa trees in the Gold Coast [Kay G.B. 1972: 272-7]. Findings from the West African Cocoa Research Institute indicated that the disease was spreading rapidly. Based on their own research and their experiences of the situation in other parts of the world, they recommended the cutting out of all diseased plants as the only effective remedy for the disease.

This was a time anti-colonial sentiment was at its peak in the Gold Coast as noted by J. B. Danquah that '... the Government's scheme for eradication of the disease is scientifically sound but politically inexpedient' [Kay G.B. 1972: 274]. The cutting-out campaign was poorly executed; the farmers were inadequately informed about the nature of the disease; there was indiscriminate cutting of both healthy and diseased trees since labourers were paid according to the number of trees they cut; and cutting-out squads sometimes arrived on farms without notifying the farmers concerned [Danquah F. 2003: 66]. These among others were some of the lapses accompanying the cutting-out process, yet political implications were assigned to the whole exercise. There were rumours that Britain had intended to destroy the cocoa industry in the Gold Coast before selling the country to the United States, and that, the large expatriate firms like the UAC had wished to reduce West African production of cocoa and to establish big plantations in the Far East or in East Africa [Kay G.B. 1972: 272-7]. This disaffection from the cocoa sector garnered more agitation 
against the colonial authorities leading to the outbreak of the 1948 riots in the Gold Coast.

However, later discoveries like 'Gammalin 20' insecticide and 'misblowers' became a major breakthrough in the fight against the Swollen Shoot infection. In fact, this placed a strong weapon in the hands of farmers against Capsids. Eventually, by 1961, the Swollen Shoot Disease had become a thing of the past [PRAAD Accra (RG7/2/245)].

When the C. P. P assumed power in 1951, it started mixing economic matters with political power. This translated into series of amendments concerning the cocoa industry and the Cocoa Marketing Board Ordinance of 1947. Initially formed to address and stabilize the fluctuations in cocoa prices, the Cocoa Marketing Board (CMB) became an instrument of the ruling party and its policies thereby, interrupting the independence of the body concerning cocoa pricing. In essence, civil servants were all obliged to comply with the provisions of the Minister, who was himself a representative of the party. At several instances, Board meetings were reduced to a formality to ratify either the decisions taking outside by the party, the directives of a minister or of the president [PRAAD Accra (RG7/2/245)].

In addition to the challenges caused to farmers, issues concerned with the cocoa industry affected the political landscape of the country once again, delaying the attainment of for another three years. The cocoa question contributed to the formation of a new political party in September 1954, the National Liberation Movement (NLM). The NLM placed a strong demand for fresh elections even though such elections had just been held three months earlier in June [PRAAD Accra (RG7/2/245)].

It needs to be pointed out that other factors contributed to the political situation such as Asante protest against what it called cheating by the Vanlare Commission's review of constituencies, the traditional rulers' disaffection with the 1951 local government system, and the disenchantment of some of the Asante Convention People's Party youth with some of the activities and policies of their party. ${ }^{3}$ What then was the specific issue at stake? The fourth issue in this matter was the introduction of the Cocoa Duty and Development Funds (Amendment) Bill in the Legislative

3 The people of Asante demanded 30 seats instead of 21 as provided for by the Vanlare Commission. In reviewing the number of seats allocated to each region in the pending elections, the Northern Territories was given 26 and Asante 21, while they both held 19 previously. 
Assembly in August 1954 by the Minister of Finance, K. A. Gbedemah [Okyere V. 2000: 22]. Enactment of the bill brought a dispute between the cocoa farmers and the government.

The world price for cocoa was quite high, but the government by the requirements of the Bill had attempted to pay low prices to the farmers. The farmers had received 80s in 1951-1952 when the world price was $£ 245$ a ton [United Nations 1954: 19]. At the time of introducing the Bill, the world price was over $£ 450$ a ton, but instead of increasing the local price, the government proposed $72 \mathrm{~s}$ to be paid to the farmers for a period of 4 years [Rabinowitz S.B. 2013: 18]. Meanwhile in the campaigns leading to elections, Nkrumah had promised the farmers an increase in the price of cocoa to $£ 5$ per load if elected to power. Following his election, the farmers expected their reward from him, but to their chagrin, the cocoa price was pegged at $£ 312$ s. per load. The farmers delegated a group to Accra to petition for an increase of only 8s. to round the figure up to up to $£ 4$, but this was not granted [Austin D. 1964: 160-1]. Back in Kumase, an all-farmers' meeting was convened to deliberate on the next step to take, but threats from the CPP disbanded them and caused the flight of some of them from the country. The aggrieved traditional rulers of Asante and Akyem Abuakwa and the disgruntled members of the Asante CPP seized the opportunity to break away from the CPP, formed the National Liberation Movement (NLM) and placed a very strong demand for fresh elections [Austin D. 1964].

Singing Asante war songs, beating drums and firing musketry, the discontented groups met at the Prince of Wales Park in Kumase on 19 $9^{\text {th }}$ September, 1954 to launch the new party- the National Liberation Movement (NLM). The party demanded for fresh elections and visited a regime of violence on Kumase. The peak of the violence was the murder of the NLM chief propaganda secretary, E. Y. Baffoe by the regional propaganda secretary of the CPP, Twumasi-Ankrah on $9^{\text {th }}$ October 1955 [Austin D. 1964]. Though the culprit was tried and sentenced to death by hanging, the NLM refused to be placated. Mass destruction of property, breaking up of rallies, violent clashes and murders became rampant in Kumase, to the extent that some CPP members in Kumase had to flee to Accra and for about two to three years--, no CPP minister ventured to enter Kumase. The tensed situation necessitated serious intervention [Austin D. 1964].

To this effect, the British Government sent Sir Frederick Bourne to the Gold Coast to settle the impasse. Arriving in September 1955, his commission known as the Bourne's Commission and its recommendations were 
disregarded by the NLM, which stuck strictly to its demand for fresh elections. Nkrumah also attempted to solve the problem by convening the Achimota Conference to which he invited all interest groups. The NLM again refused to attend the conference [Okyere V. 2000: 166]. Against these odds, the British government yielded to the NLM demand for fresh elections which were duly held in July 1956. The massive support for the NLM perhaps gave the erroneous impression that the party would win the elections, but it became a big surprise when the CPP emerged victorious in the elections while the NLM registered a feeble performance, bringing it to a natural death. The place of cocoa in Ghanaian politics is therefore significant and the crop can indeed be classified as a determinant in the political arena.

\section{THE SOCIO-CULTURAL AND RELIGIOUS IMPACT OF COCOA}

In Ghana, cocoa is mostly grown in six regions of the country including Eastern, Asante, Western, and some parts of Brong-Ahafo, Central and Volta Regions. Migration therefore offers the means by which the rest of the country and other parts of West Africa have been integrated into cocoa culture. It is through the same means that the golden pod itself was brought into the country. What therefore is the relationship between migration and the cocoa industry in Ghana? Three types of migrants can be identified in this regard. Internally, the first type of migration related to cocoa occurred among the peoples of present day Eastern Region. As the stronghold of the Basel Mission, this was where Tetteh Quarshie started his experimentation. In the early 1890s, these migrations involved Akwapim migrant farmers from Aburi, Mampong, Mamfe, Larteh and Akropong [Hill P. 1970: 23]. These migrants moved to western and north-western Akwapim, near areas around Adawso where the land was/is suitable for production of the crop. Also among this category of migrants were the Shai, Krobo, Ga and Anum/Boso.

The expansion and spread of cocoa production to other parts of the southern sector in Ghana ushered in a second type of migration. People in the savannah zones, especially those in the northern savannah moved to the south to work in the cocoa farms for wage income. In addition, people from other parts of West Africa and neighbouring countries migrated to Southern Ghana to partake in cocoa production. One way in which co- 
coa farmers in the south, particularly in Asante and Brong-Ahafo made up for the labour shortage was to arrange with truck drivers plying between Kumase and some northern towns like Bawku, Bolga and Navrongo to recruit from these northern towns for a fee. Some of the cocoa famers made the journey themselves to negotiate for recruits while others relied on agents resident in Kumase [Adomako-Sarfo J. 1974: 150]. The third category of migrants were those from other parts of West Africa such as the Mossi migrants from Burkina Faso, and others from Mali, Togo and Niger and other parts of Nigeria [Adomako-Sarfo J. 1974: 138-9]. However, the implementation of the Aliens Compliance Order in 1969-70 resulted in labour shortage following the expulsion of illegal migrants from other parts of West Africa.

Evidence of the presence of such alien migrants in the cocoa growing areas of southern Ghana can be found in a study involving 107 annual labourers from nine villages in Western Brong-Ahafo. Of the total number, 47 were from northern Ghana, 42 were Mossi from Burkina Faso, 5 from Ogbomosho in western Nigeria, while the remainder claimed they were non-Ghanaians but were uncertain about their nationalities [AdomakoSarfo J. 1974: 146]. Burkina Faso and Mali are landlocked countries lying north of Ghana and were both French colonies where the people were subjected to a harsh taxation system. The situation compelled many people from these countries to migrate to cocoa growing and mining areas in Ghana and Cote d'Ivoire in particular to work and settle their tax obligations [Crowder M. 1968: 337]. The cocoa revolution therefore intensified migration both internally and internationally and brought about intermingling and integration of ethnic stocks.

The impact of these migrations cannot be overemphasized. Though men, women and children were all involved in these cocoa-related migrations in the Eastern Region, the men often constituted the majority. Debrunner observed that in 1913, just about 50 old women and 10 old men were permanently domiciled in the Christian quarters at Larteh. Converts of the Basel Mission who numbered up to about 2000 had cultivated the habit of moving out to stay for very long periods in the cocoa areas in the year [Debrunner H.W. 1967: 252-4]. As a result of this, school children were left hungry since all adult relatives or caterers were gone and food crop production was neglected. Similarly, in Anum, Boso and Toseng in the Volta Region, the population had decreased from 5,603 to 1, 500-2,000 between 1911 and 1917, leaving a population made up of only children and old people [Debrunner H.W. 1967: 252-4]. 
The situation also resulted in child labour and child pawning. Not all the children who migrated to the cocoa areas went on their own accord. Some were given out by relatives for a fee or for some other reward. According to a Basel Mission report, movement to the cocoa areas was not limited to any specific group but included the poor and deprived, as well as those who were even employed like teachers, catechists as well as ministers of the Gospel [Debrunner W.H. 1967: 255]. To this extent, everyone was 'infected' by the cocoa fever. Men, women, children as well as adults.

Cocoa production also affected gender relations in a number of ways. Apart from the Volta Region and some areas in the Eastern Region, all the cocoa growing areas in Ghana are matrilineal inheritance settings. For the period under consideration, migrations from northern Ghana to cocoa farms in the south were cyclical in nature and undertaken by males. Women's involvement in the cocoa business from that part of the country could therefore be expected to very minimal, perhaps only to the extent of benefitting from remittances from their male relatives who participated in the activity. The Volta Region is also a patrilineal setting in which women's access to land is a difficult matter. Therefore, despite the cultivation of cocoa in some areas of the region, the menfolk were most likely to be the ones in control regarding ownership of cocoa farms.

In highly entrenched matrilineal places, there is evidence of women's active involvement in the affairs of cocoa production [Tashjian V.B., Allman, J. 2002: 237-59]. By age 20, Auntie Maggie from the Brong-Ahafo Region had established her own cocoa farm through experience gained by working on the cocoa farm of her parents [Tashjian V.B., Allman, J. 2002: 237-59]. She subsequently established several other cocoa farms with each measuring up to about five acres. Her involvement in cocoa production enhanced her economic status and that of her children. Therefore women's labour in cocoa production, especially in cases where wives and children moved to stay with husbands on cocoa farms became significant in conjugal unions. In the early years of the cocoa revolution in Asante, women were tied to their husbands as sources of labour in cocoa production but benefitted little from their labour since the early cocoa farms in Asante were owned by men and were not regarded as joint family businesses. Therefore, in case of divorce, the women parted with no share of the cocoa business.

However, with some more decades into the twentieth century, the situation was to change with Asante women asserting themselves and own- 
ing farms in their own right, or demanding compensation from cocoa proceeds in times of divorce. Cocoa therefore helped to transform and redefine gender relations in Asante to the advantage of women by opening new avenues for them for their own emancipation.

Captured below is a highlife song of the 1950s depicting the significance of cocoa in the life of the Asante people:

If you want to send your children to school, it is cocoa,

If you want to build your house, it is cocoa,

If you want to marry, it is cocoa,

If you want to buy cloth, it is cocoa,

If you want to buy a lorry, it is cocoa,

Whatever you want to do in this world,

It is with cocoa money that you do it [Tashjian V.B., Allman, J. 2002: 238].

There also existed a marked relationship between religion and cocoa production. The Christian religion in particular was affected in many ways by the 'cocoa fever'. The Basel missionaries as already pointed out were among the earliest to have experimented with the crop. The successful planting and expansion of cocoa in this period meant for them an opportunity to continue from where they had failed. The Basel Mission Trading Company (BMTC) for instance took to the marketing of the product. They established a system of buying stations and used canoes to transport cocoa to the coast [Debrunner W. 1967: 253]. Also, the movement of Christian converts into the cocoa areas implied that missionaries had to move to follow them. The Basel Mission had to build outstations at places such as Adawso, Mangoase, Suhum, Nsawam and Asamankese to cater for the spiritual needs of their converts who had moved into these areas to grow cocoa. Where outstations were not set up, pastors had to commute to conduct church services. When this alternative was not possible church members became completely detached from their church. The following report in 1914 throws more light on the situation:

\footnotetext{
'We realized that about 2000 Akwapim Christians live on their cocoa plantations between the rivers Densu and Ayensu. Several of them have not taken part in Church services for years. Catechist Atiemo visits these Christians from his station at Asuogya' [Debrunner H.W. 1967: 252-4].
}

Cocoa brought money into circulation and enhanced the economic status of many people and Christian Missions also benefited from this economic boom. However, it also came with other negative consequences 
for the Churches. Financial contributions to the Church and building of schools and chapels were some of the benefits derived by the Church from the cocoa boom, and even there are reports of other generous contributions to the Church in loads of cocoa instead of cash. Yet, numerous complaints from Church sources indicate that the negative impact of cocoa was quite significant. Charles Martinson, a catechist at Apasare told his congregation that 'I am sure that most of you think more of cocoa than of God...' [Debrunner H.W. 1967: 254]. Also, farming and cocoa farming in particular bred Asante resistance to missionary activities in the region. Asante resistance to Christian missionary activities up to about the end of the nineteenth century is evidenced by the Asantehene's famous response to a request to start a mission school that:

...You must understand that we will not select children for education, for the Asante children have better work to do than to sit down all day idly to learn "Hoy! Hoy! Hoy!" They have to fan their parents, and do other work which is much better' [Debrunner H.W. 1967: 180].

This famous saying of the Asantehene reflected the high degree to which the Asante resisted missionary 'intrusion'. However, according to Debrunner, the cocoa revolution changed the situation for the better. He noted that, 'cocoa-growing began to assume more and more importance in Asante and this brought social changes in which literacy was an asset' [Debrunner H.W. 1967: 312]. Learning and educating farmers and labourers on cocoa production and dynamics involved in the sale of the product requires some literacy skills. Hence, and since the provision of formal education was largely in the hands of the Christian missions in this period, the Asante could no longer turn their back on the missionaries. However, also tied to this was the defeat of the Asante by the British in the Yaa Asantewaa War at the beginning of the twentieth century and the return of the exiled Asantehene Nana Prempe I, as a baptised Anglican with the name Edward and the Queen-Mother baptised as Victoria, after more than two decades stay in the Seychelles.

If Christianity was this way affected by cocoa, one would get the impression that the religion to some extent was deeply rooted among Ghanaians. However, the resort by many migrants to traditional religion for security in the same period implied that the indigenous Christians of the period were not altogether fully-fledged Christians. The high rate of immorality which usually accompanied such settlements composed of circular migrants generated a sense of insecurity among the people. Evidence 
that many people resorted to traditional religious methods for protection against witchcraft and the influence of other 'evil forces' was the spread of anti-witchcraft movements and cults in the late nineteenth and early twentieth centuries. Some of these included the spread of Sakrobundi and Aberewa from Brong-Ahafo and Asante to other parts of the country [McCaskie T. 2004: 82-135, Debrunner H.W. 1967: 255]. Others included Katawere of the Akim-Kotoku, Dente from Kete Krakye, Kotoklo and Nadu among the Krobo and Yehwe among the Ewe in the Volta Region [Debrunner H.W. 1967: 255]. Cocoa has therefore had both positive and negative impact on the religious front in the country.

The impact of the 'cocoa revolution on education has also been considerable. The first educational institutions related to cocoa production were research oriented aimed at improving the standard and quality of the crop. In this regard, the Gold Coast Department of Agriculture established the Central Cocoa Research Station in 1938 [Tetteh S.A.2019: 21]. In 1944, it was renamed the West African Cocoa Research Institute (WACRI) with branches in Nigeria and Sierra Leone. After independence, WACRI was dissolved and the Cocoa Research Institute of Ghana formed to replace it in 1962 [Tetteh S.A. 2019: 37].

Apart from these research institutions, a significant contribution of cocoa to the education sector is the cocoa scholarships for students in secondary and tertiary institutions. The Cocoa Marketing Board was a major contributor to such scholarships in the post-independence era. Through earnings from cocoa, children of Christian cocoa farmers attained higher levels in education as lawyers, civil servants, bankers and economists just to mention a few [Akrofi-Christaller Institute 2017]. Such people have contributed in various capacities to the development of Ghana.

Traditionally, bye-products of cocoa were used in local industries to generate employment for many people. Potash which is derived from burnt dry cocoa pod husk is used in the local soap industry to produce a local brand known popularly as Alata Samina [Darst B.C. 1991: 104]. This locally manufactured soap is highly patronised and offers employment opportunities for many people. Potash can also be used as fertilizer while the cocoa bean shells can serve as organic mulch and soil conditioner for gardens [Darst B.C. 1991: 105]. 


\section{CONCLUSION}

The current discourse paid attention to cocoa production in Ghana. Importantly, it pays attention to the implications of cocoa production to fully appreciate the impact of cocoa production in Ghana between 1879 and 1976. The discussions span the economy, politics and social and cultural implications of cocoa production in Ghana. Both the existing and current debate on cocoa have shown that, as the major cash crop in Ghana, cocoa has contributed significantly to the development of the country through time.

The discussions point to the fact that economically, the cultivation and expansion of cocoa production resulted in commercialization and individualization of lands and led to the development of rural communities within the period under review. Concerning politics, cocoa production resulted in new debates among colonial authorities. It has been shown that, at least, the increase in cocoa production prompted the colonial administration to strategize plans for the establishment of cocoa processing factory in Ghana.

When Ghana gained her independence, the government of the C.P.P faced opposition from cocoa producers in Asante who tended to form the National Liberation Movement. Importantly, the actions of the NLM compelled the government of Nkrumah to address the low cocoa producer price in the country. On the social grounds, cocoa production saw the development of cities and rural areas. Specifically, social amenities were provided for cocoa development areas.

Based on the study, it can be concluded that though an agricultural endeavour, cocoa can no longer be said to belong to that sphere alone in contemporary times. Cocoa and its associated gains have permeated the entire life of Ghanaians since the product's inception. Economically, it is a source of employment enhancing the livelihood of many people. It continues to generate foreign exchange, add to government revenue and has transformed many rural economies. Socially, it has serious implications for migration, religion, gender relations, and education among others. Cocoa has also featured prominently in Ghanaian politics and indeed one cannot but agree with the saying that "Ghana is cocoa and cocoa is Ghana". 


\section{REFERENCES}

\section{Historical Sources}

PRAAD Accra (CSO 8/2/40), Cocoa Storage -Accra Beach.

PRAAD Accra (CSO 8/2/85), Cacao Farms: Abandonment and Neglect of Cocoa Farm During Depression in the Industry in Favor of the Increased Cultivation of Food Crop.

PRAAD Accra (RG 7/1/196). Cocoa Beans Processing.

PRAAD Accra (RG7/2/245), Infestation Control Unit. CMB Newsletter: A Quarterly Publication, No. 42. September, 1969.

PRAAD Accra (RG7/2/245), The Board and Party Politics CMB Newsletter: A Quarterly Publication, No. 42. September, 1969.

\section{Literature Sources:}

Adomako-Sarfo J. (1974), The Effects of the Expulsion of Migrant Workers on Ghana's Economy, With Particular Reference to the Cocoa Industry, [in:] Amin S. (ed.), Modern Migrations in Western Africa, Oxford University Press, Oxford, 138-152.

Adu-Gyamfi S., Bempong E., Yartey H. T., Darkwa B.D. (2020), British Land Policies in the Gold Coast and Her Relations with Asante, Studia Historiae Oeconomicae, 38, 163-181.

Agbodeka F. (1992), An Economic History of Ghana. From the Earliest Times, Ghana Universities Press, Accra.

Akrofi-Christaller Institute of Theology, Mission and Culture, www. Acighana.org. Accessed on $4^{\text {th }}$ February, 2017.

Akuamoa G.K. (2011), Kwame, the Last Slave from West Africa, Triangle Circle, Accra.

Austin D. (1964), Politics in Ghana, 1947-1960, Oxford University Press, London.

Boahen A.A. (1975), Ghana: Evolution and Change in the Nineteenth and Twentieth Centuries, Longman Group Ltd, London.

Crowder M. (1968), West Africa under Colonial Rule, Ethiope Publishing Corporation, Benin.

Danquah K.F. (2003), Sustaining a West African Cocoa Economy: Agricultural Science and the Swollen Shoot Contagion in Ghana, 1936-1965, African Economic History, 31, 43-74.

Darkwah S.A., Verter N. (2014), An Empirical Analysis of Cocoa Bean Production in Ghana, European Scientific Journal, 10/16, 295-306.

Darst B.C. (1991), Development of the Potash Fertilizer Industry, Fertilizer Research, 28(1), 103 107.

Debrunner H.W. (1967), A History of Christianity in Ghana, Waterville Publishing House, Accra.

Hill P. (1970), Studies in Rural Capitalism in West Africa, Cambridge University Press, Cambridge.

Kay G.B. (1972), The Political Economy of Colonialism in Ghana: A Collection of Documents and Statistics, 1900-1960, Cambridge University Press, Cambridge.

Kimble D. (1963), A Political History of Ghana 1850-1928, Oxford University Press, Oxford.

McCaskie T.C. (2004), Sakrobundi ne Aberewa: Sei Kwaku the Witch-finder in the Akan World, Transactions of the Historical Society of Ghana, New Series No. 8, 82-135

Metcalfe G.E. (1964), Great Britain and Ghana: Documents of Ghana History 1807-1957, Thomas Nelson \& Sons Ltd, London.

Okyere V. (2000), Ghana: A Historical Survey, Vinojab Publications, Accra. 
Oppong-Boateng J. (2014), Economic Enterprises of the Basel Mission Society in the Gold Coast: A Study of the Basel Mission Trading Company from 1859 to 1917, University of Ghana, Legon (Diss.).

Rabinowitz S.B. (2013), Urban-Bias and the Roots of Political Instability: The Case for the Strategic Importance of the Rural Periphery in Sub-Saharan Africa, University of California, Berkeley (Diss.).

Tashjian V.B., Allman, J. (2002), Marrying and Marriage on a Shifting Terrain: Reconfigurations of Power and Authority in Early Colonial Asante, [in:] Jean A., Susan G., Nakanyike M. (eds.), Women in African Colonial Histories, Indiana University Press, Indiana, 237-259.

Tetteh S.A. (2019), History of Cocoa Research Institute of Ghana, Tafo1938-2008, University of Ghana, Legon (Diss.).

United Nations (1954). United Nations Visiting/ Mission to Trust Territories in West Africa, 1952: Report on Togoland under United Kingdom Administration Together With Related Documents, United Nations, New York.

Wessel M., Quist-Wessel P.M.F. (2015), Cocoa Production in West Africa, a Review and Analysis of Recent Developments, NJAS-Wageningen Journal of Life Sciences, 7/4, 1-7.

Mariama Marciana Kuusaana is a lecturer in History in the Department of History and Political Studies, at the Kwame Nkrumah University of Science and Technology, Kumasi. Her areas of interest include Migration, Social and Colonial History, Women's History, and some aspects of Regional History, such as Africa, the USA and Russia.

Samuel Adu-Gyamfi is a Senior Lecturer in the Department of History and Political Studies of Kwame Nkrumah University of Science and Technology (KNUST), Kumasi-Ghana. His research focus is in Applied History, Environmental History, Health Policy, Social Policy, Social Medicine, Societal Studies and Social Change. Through Applied History, he makes explicit attempts to illuminate current challenges and choices by analyzing historical precedents and analogues. He begins with a current choice or predicament and provides a perspective from history.

Benjamin Dompreh Darkwa has secured admission and funding to study for a Masters Degree in History at the University of Alberta, Canada. Benjamin primarily focuses his research on the history of medicine, environment, culture, social and economic development. Specifically, his interest is linked to how the discourses of medicine, health, culture, social and economic development have been shaped throughout history. 